\title{
To Investigate the Rate of Release of Boron from Different Sources and Levels of Boron at Varying Period of Incubation
}

\author{
P.J. Rathod* and N.M. Zalawadia \\ Krishi Vigyan Kendra, Lokbharti gramvidhyapith, Sanosara, Shihor, \\ Bhavnagar-364230, India \\ *Corresponding author
}

A B S T R A C T

Key words

Boron, Sources, Level, Boric acid, Borax, Agricol and incubation

Article Info

Accepted:

20 June 2018

Available Online:

10 July 2018
The time of incubation had the pronounced effect on boron availability. The boron availability of each product increased up to $45^{\text {th }}$ days of incubation period, and then it was decreased. Availability of boron seems to have direct relationship with the quantity of applied boron. Thus, the overall availability of boron increased with the increasing dose of applied boron sources. Among the different sources of boron, the rate of release of available boron was highest in Boric acid followed by Borax and Agricol. The interaction effect of different sources and periods was found significant. The highest availability of boron was registered at $45^{\text {th }}$ days of incubation period with $10 \mathrm{ppm}$ Boric acid treatment.

\section{Introduction}

Boron is one of the seven essential micronutrients required for normal growth and development of plant. The original source of B in most soils is tourmaline which contains 3$4 \% \mathrm{~B}$. It is quite resistant to weathering hence the release of $\mathrm{B}$ from it is quite slow. Boron being the only element that is normally present in the soil solution as a non ionized molecule $\left(\mathrm{H}_{3} \mathrm{BO}_{3}\right)$ over the $\mathrm{pH}$ range suitable for plant growth. It helps in increasing the permeability of cell membranes in the plants. It involves in sugar translocation, metabolism of carbohydrates and auxin, flower fertility, cellular activities and chlorophyll synthesis. It also plays a vital role in protein synthesis and related to calcium, potassium metabolisms in plants (Tisdale et al., 1985).

In recent years, the importance of micronutrients in increasing agricultural production and correcting deficiencies in plants has been greatly realized. In India, the deficiencies of micronutrients have been observed in the light texture and calcareous soils. The situation has been further aggravated with the introduction of high 
yielding crop varieties, intensive cropping system, heavy fertilization with high purity grade fertilizers and decrease in the use of bulky organic manures and recycling of crop residues. The accompanied changes in the soil management practices also frequently alter the micronutrient availability. In order to maintain the level of productivity of the soils, it is desired to keep the complete account in their status and changes being taking place with regards to their substitute and production.

(a) Three sources of boron

\section{Materials and Methods}

\section{Incubation study}

The details of experiment are given below.

1. Design of experiment: Completely Randomized Design with 63 treatment combinations.

2. Treatment: There were three sources of boron and seven levels of boron and six period intervals as follows.

\begin{tabular}{|c|l|}
\hline Symbol & Sources \\
\hline $\mathbf{S}_{\mathbf{1}}$ & Agricol (Coleminite) \\
\hline $\mathbf{S}_{\mathbf{2}}$ & Borax crystals \\
\hline $\mathbf{S}_{\mathbf{3}}$ & Boric acid \\
\hline
\end{tabular}

(b) Seven levels of boron

\begin{tabular}{|c|c|c|}
\hline \multicolumn{2}{|l|}{ Symbol } & Levels \\
\hline$L_{0}$ & & $0.0 \mathrm{mg} \mathrm{kg}^{-1}$ \\
\hline $\mathrm{L}_{1}$ & & $1.0 \mathrm{mg} \mathrm{kg}^{-1}$ \\
\hline$L_{2}$ & & $2.0 \mathrm{mg} \mathrm{kg}^{-1}$ \\
\hline$L_{3}$ & & $4.0 \mathrm{mg} \mathrm{kg}^{-1}$ \\
\hline $\mathrm{L}_{4}$ & & $6.0 \mathrm{mg} \mathrm{kg}^{-1}$ \\
\hline $\mathrm{L}_{5}$ & & $8.0 \mathrm{mg} \mathrm{kg}^{-1}$ \\
\hline $\mathrm{L}_{6}$ & & $10 \mathrm{mg} \mathrm{kg}^{-1}$ \\
\hline (c) Replication & : & 3 (three) \\
\hline (d) Location & : & $\begin{array}{l}\text { U. G. Laboratory, Department of Agril. Chemistry } \\
\text { and Soil Science, } \\
\text { College of Agriculture, } \\
\text { J. A. U. Junagadh. }\end{array}$ \\
\hline (e) Moisture maintained & : & At field capacity \\
\hline
\end{tabular}

\section{Incubation period}

There were six different periods of incubation. The sampling done at the intervals as mentioned in Table A.

\section{Method of incubation}

One $\mathrm{kg}$ soil was taken in a plastic bowel and the soil was treated with seven levels of boron $\left(0.0,1.0,2.0,4.0,6.0,8.0\right.$, and $\left.10 \mathrm{mgkg}^{-1}\right)$ and three source of boron (Agricol, Borax crystal and Boric acid) as per treatments in triplicate at room temperature $\left(27^{\circ}-30^{\circ} \mathrm{C}\right)$ in the laboratory. The soil moisture content was maintained at field capacity of the soil and loss in water content in soil was made up throughout the incubation period by addition the water as determined by the loss in weight of bowel soils.

Periodical soil sampling at each interval $\left(15^{\text {th }}\right.$, 
$30^{\text {th }}, 45^{\text {th }}, 60^{\text {th }}, 75^{\text {th }}$ and $\left.90^{\text {th }}\right)$ was done with the help of a plastic tube. The soil sampling was done from 3 spots of each bowel considering entire depth of bowel. The soil was air dried, passed in $2 \mathrm{~mm}$ sieve and analyzed for hot water soluble (HWS) boron. The incubation study was started on $11^{\text {th }}$ June, 2007 and completed $11^{\text {th }}$ August, 2007.

\section{Results and Discussion}

\section{Effect of different sources of boron and incubation periods on availability of boron}

The data regarding the availability of boron as affected by different sources of boron and incubation periods are reported in table 1 . The result revealed that the different sources of boron produced significant effect on availability of boron. The maximum availability of boron was registered with Boric acid (3.57 ppm), while lowest was observed with Agricol product (0.96 ppm). All the sources were significant with each other. Among the different sources, the rate of release of available boron was highest in Boric acid followed by Borax and Agricol treatments.

A close look at this table reveals that there was an apparent effect of time of incubation on the availability of boron (Table 1). The mean values of boron availability for different time intervals show that there was significant effect of time of incubation, which increased the availability of boron up to $45^{\text {th }}$ days period. Then it was significantly decreased with all the sources. The maximum availability was observed at $45^{\text {th }}$ days period (2.69 ppm) while beyond this period it was decreased up to $90^{\text {th }}$ days. The lowest availability was observed at $90^{\text {th }}$ days period (1.37 ppm). The interaction effect of different sources and periods was found significant. The highest $(4.57 \mathrm{ppm})$ availability of boron was registered at $45^{\text {th }}$ days with boric acid treatment, while lowest $(0.76 \mathrm{ppm})$ boron availability was found at $15^{\text {th }}$ days with Agricol treatment. In the experimental soil, the trend of change in HWS-B content was found to record a significant and gradual decrease with the advancement of incubation period. Further, at later stages of incubation, greater amounts of HWS-B content transformed into some non-exchangeable forms as compared to early period of incubation. These results are in line with the findings by Gupta (1968), Khanh et al., (2005) and Girish Chander et al., (2007). The adsorption of boron on clay minerals and fixation and exchange (Keren and Bingham, 1994) probably reduced these available contents in soil. This may be attributed to fixation and/or complexation of B with organic and inorganic components of the soil (Evans and Sparks (1983).

\section{Effect of different sources and levels of boron on availability of boron}

The results of different sources and levels of boron on availability of boron are reported in table 2. The different sources of boron produced significant effect on rate of release of available boron. The maximum availability of boron was registered under Boric acid (3.57 ppm), while lowest was observed under Agricol (0.96 ppm).

The Agricol significantly increased availability of boron with increase in level of boron except $1 \mathrm{ppm}$ level, where it was at par with 0 level of boron. The similar trend was also observed in case of Borax and Boric acid. The highest (3.98 ppm) availability was recorded at $10 \mathrm{ppm}$ level of boron concentration. The lowest $(0.54 \mathrm{ppm})$ availability was registered at $0 \mathrm{ppm}$ of boron concentration.

The interaction effect of level and sources of boron on boron availability was found significant. The maximum availability of 
boron (7.37 ppm) was observed in Boric acid at $10 \mathrm{ppm}$ application of boron concentration, while minimum availability of boron $(0.53$ ppm) was observed in Agricol at 0 ppm level of concentration i.e. no application of boron.

It is clearly indicated that the availability of boron in each source significantly increased with increase in levels of boron. The application of boron obvious to increase the available boron content in soil, Prasad and Byrne (1975) reported that the boron concentration significantly improved boron status in soil. More or less similar results were also reported by Evans and Sparks (1983) and Girish Chander et al., (2007).

Interaction effect of boron levels, sources and incubation periods on boron availability

The pooled data regarding the effect of boron levels, boron sources and incubation periods are presented in Table 3 . The pooled results of interaction over entire period of incubation showed significant effect. It was found that at zero level of boron to $10 \mathrm{ppm}$ boron application with different sources, the availability of boron increased but the rate of increase was much higher when boron was applied @ 10 ppm. It is seen that although the interaction was significant, the trend of boron availability at different incubation period did not found consistent. The trend was almost similar when the combined effect of boron sources and boron level was examined at individual incubation periods.

The interaction of period-source-level was significant. It is the point to note that when levels of boron, source and incubation period increase simultaneously the rate of increase in availability of boron was more than at any constant level of factor. The combination of $10 \mathrm{ppm}$ boron, $90^{\text {th }}$ day incubation and boric acid source increased the availability of boron by four times compared to the combination of no application of boron at $15^{\text {th }}$ days of incubation in Agricol. The availability of boron increased to a grater extent by combined application of period, level and source than varying in levels of any single factor. These results are in affirmation with those of earlier workers Keren and Bingham, (1994); Khanh et al., (2005) and Girish Chander et al., (2007).

Table.1 Effect of different sources of boron and incubation periods on availability of boron

(ppm)

\begin{tabular}{|c|c|c|c|c|}
\hline \multirow{2}{*}{ Treatments } & \multicolumn{3}{|c|}{ Sources of boron (ppm) } & \multirow{2}{*}{ Mean } \\
\cline { 2 - 5 } & Agricol $-\mathrm{S}_{1}$ & Borax $-\mathrm{S}_{2}$ & Boric acid $-\mathrm{S}_{3}$ & \\
\hline $\mathbf{1 5}^{\text {th }}$ days & 0.76 & 1.04 & 3.79 & $\mathbf{1 . 8 6}$ \\
\hline $\mathbf{3 0}^{\text {th }}$ days & 0.88 & 1.41 & 4.19 & $\mathbf{2 . 1 6}$ \\
\hline $\mathbf{4 5}^{\text {th }}$ days & 1.40 & 2.09 & 4.57 & $\mathbf{2 . 6 9}$ \\
\hline $\mathbf{6 0}^{\text {th }}$ days & 1.09 & 1.87 & 3.71 & $\mathbf{2 . 2 2}$ \\
\hline $\mathbf{7 5}^{\text {th }}$ days & 0.93 & 1.46 & 2.93 & $\mathbf{1 . 7 7}$ \\
\hline $\mathbf{9 0}^{\text {th }}$ days & 0.68 & 1.18 & 2.24 & $\mathbf{1 . 3 7}$ \\
\hline Mean & $\mathbf{0 . 9 6}$ & $\mathbf{1 . 5 1}$ & $\mathbf{3 . 5 7}$ & \\
\hline Treatment & S.Em+ & C.D. at $5 \%$ & C.V. $\%$ & \\
\hline $\mathbf{S}$ & 0.016 & 0.046 & 10.39 & \\
\hline $\mathbf{P}$ & 0.018 & 0.051 & & \\
\hline S X P & $\mathbf{0 . 0 4 1}$ & $\mathbf{0 . 1 2 4}$ & & \\
\hline
\end{tabular}


Table.A Incubation period

\begin{tabular}{|l|l|l|}
\hline Sr.No & Particulars & Treatments \\
\hline 1. & Fifteen day after application of B & $\mathbf{1 5}^{\text {th }}$ \\
\hline 2. & Thirty day after application of B & $\mathbf{3 0}^{\text {th }}$ \\
\hline 3. & Forty five day after application of B & $\mathbf{4 5}^{\text {th }}$ \\
\hline 4. & Sixty day after application of B & $\mathbf{6 0}^{\text {th }}$ \\
\hline 5. & Seventy five day after application of B & $\mathbf{7 5}^{\text {th }}$ \\
\hline 6. & Ninety day after application of B & $\mathbf{9 0}^{\text {th }}$ \\
\hline
\end{tabular}

Table.2 Effect of different sources and levels of boron on availability of boron (ppm)

\begin{tabular}{|c|c|c|c|c|}
\hline \multirow[t]{2}{*}{ Treatments } & \multicolumn{3}{|c|}{ Sources of boron (ppm) } & \multirow[t]{2}{*}{ Mean } \\
\hline & Agricol - $S_{1}$ & Borax $-S_{2}$ & Boric acid $-\mathrm{S}_{3}$ & \\
\hline 0 ppm & 0.53 & 0.53 & 0.56 & 0.54 \\
\hline 1 ppm & 0.55 & 0.72 & 1.24 & 0.84 \\
\hline 2 ppm & 0.64 & 0.83 & 2.31 & 1.26 \\
\hline 4 ppm & 0.88 & 1.35 & 3.32 & 1.85 \\
\hline 6 ppm & 0.94 & 1.80 & 4.45 & 2.40 \\
\hline 8 ppm & 1.47 & 2.45 & 5.74 & 3.22 \\
\hline 10 ppm & 1.71 & 2.86 & 7.37 & 3.98 \\
\hline Mean & 0.96 & 1.51 & 3.57 & \\
\hline Treatment & S.Em+ & C.D. at $5 \%$ & C.V. \% & \\
\hline $\mathbf{S}$ & 0.016 & 0.046 & 10.39 & \\
\hline $\mathbf{L}$ & 0.020 & 0.055 & & \\
\hline SX L & 0.044 & 0.124 & & \\
\hline
\end{tabular}

Table.3 Interaction effect of boron levels, sources and incubation periods on boron availability

\begin{tabular}{|l|l|c|c|c|}
\hline Incubation periods & Levels of boron & \multicolumn{3}{|c|}{ Sources of boron $(\mathrm{ppm})$} \\
\cline { 3 - 5 } & & Agricol & Borax & Boric acid \\
\hline 15 day & $0 \mathrm{ppm}$ & 0.38 & 0.44 & 0.46 \\
\hline & $1 \mathrm{ppm}$ & 0.41 & 0.51 & 1.35 \\
\hline & $2 \mathrm{ppm}$ & 0.52 & 0.62 & 2.25 \\
\hline & $4 \mathrm{ppm}$ & 0.64 & 0.74 & 3.07 \\
\hline & $6 \mathrm{ppm}$ & 0.73 & 0.85 & 4.60 \\
\hline & $8 \mathrm{ppm}$ & 1.22 & 2.00 & 6.42 \\
\hline & $10 \mathrm{ppm}$ & 1.43 & 2.13 & 8.38 \\
\hline & $0 \mathrm{ppm}$ & 0.54 & 0.57 & 0.61 \\
\hline & $1 \mathrm{ppm}$ & 0.48 & 0.63 & 1.57 \\
\hline & $2 \mathrm{ppm}$ & 0.66 & 0.79 & 2.51 \\
\hline & $4 \mathrm{ppm}$ & 0.78 & 1.20 & 3.46 \\
\hline & $6 \mathrm{ppm}$ & 0.75 & 1.90 & 5.43 \\
\hline
\end{tabular}




\begin{tabular}{|c|c|c|c|c|}
\hline & $8 \mathrm{ppm}$ & 1.38 & 2.27 & 6.78 \\
\hline & $10 \mathrm{ppm}$ & 1.57 & 2.48 & 8.96 \\
\hline \multirow[t]{7}{*}{45 day } & $0 \mathrm{ppm}$ & 0.67 & 0.61 & 0.67 \\
\hline & $1 \mathrm{ppm}$ & 0.69 & 0.74 & 1.66 \\
\hline & $2 \mathrm{ppm}$ & 0.82 & 1.20 & 2.81 \\
\hline & 4 ppm & 1.58 & 1.91 & 4.31 \\
\hline & 6 ppm & 1.58 & 2.54 & 5.64 \\
\hline & $8 \mathrm{ppm}$ & 2.16 & 3.48 & 7.54 \\
\hline & $10 \mathrm{ppm}$ & 2.34 & 4.13 & 9.35 \\
\hline \multirow[t]{7}{*}{60 day } & $0 \mathrm{ppm}$ & 0.56 & 0.55 & 0.59 \\
\hline & 1 ppm & 0.62 & 1.30 & 0.63 \\
\hline & $2 \mathrm{ppm}$ & 0.70 & 0.98 & 2.49 \\
\hline & 4 ppm & 0.90 & 1.66 & 3.62 \\
\hline & 6 ppm & 1.07 & 2.27 & 4.40 \\
\hline & $8 \mathrm{ppm}$ & 1.80 & 2.95 & 6.01 \\
\hline & $10 \mathrm{ppm}$ & 2.01 & 3.34 & 8.20 \\
\hline \multirow[t]{7}{*}{75 day } & $0 \mathrm{ppm}$ & 0.54 & 0.53 & 0.56 \\
\hline & $1 \mathrm{ppm}$ & 0.59 & 0.62 & 1.17 \\
\hline & $2 \mathrm{ppm}$ & 0.62 & 0.77 & 2.19 \\
\hline & $4 \mathrm{ppm}$ & 0.77 & 1.39 & 3.12 \\
\hline & $6 \mathrm{ppm}$ & 0.86 & 1.90 & 3.69 \\
\hline & $8 \mathrm{ppm}$ & 1.44 & 2.32 & 4.49 \\
\hline & $10 \mathrm{ppm}$ & 1.69 & 2.70 & 5.27 \\
\hline \multirow[t]{7}{*}{90 day } & $0 \mathrm{ppm}$ & 0.48 & 0.48 & 0.46 \\
\hline & 1 ppm & 0.49 & 0.52 & 1.05 \\
\hline & 2 ppm & 0.52 & 0.62 & 1.63 \\
\hline & 4 ppm & 0.63 & 1.19 & 2.32 \\
\hline & 6 ppm & 0.64 & 1.34 & 2.95 \\
\hline & $8 \mathrm{ppm}$ & 0.82 & 1.69 & 3.22 \\
\hline & $10 \mathrm{ppm}$ & 1.90 & 2.38 & 4.06 \\
\hline Treatments & \multicolumn{2}{|c|}{ S.Em + } & C.D. at $5 \%$ & C.V. \% \\
\hline S X P X C & \multicolumn{2}{|c|}{0.10} & 0.30 & 10.39 \\
\hline
\end{tabular}

The summary and conclusion are as follows:

An incubation study was undertaken to know the effect of different sources (Boric acid, Borax and Agricol) and levels (0.0, 1.0, 2.0, $4.0,6.0,8.0$ and $10.0 \mathrm{ppm})$ of boron at various incubation periods $\left(15^{\text {th }}, 30^{\text {th }}, 45^{\text {th }}\right.$, $60^{\text {th }}, 75^{\text {th }}$, and $90^{\text {th }}$ day) on boron availability. The time of incubation had the pronounced effect on boron availability. The boron availability of each source increased up to $45^{\text {th }}$ days of incubation period, and then it was decreased. Availability of boron seems to have direct relationship with the quantity of applied boron. Thus, the overall availability of boron increased with the increasing dose of applied boron sources. The different sources of boron produced significant effect on rate of release of available boron. Among the different sources of boron, the rate of release of available boron was highest in Boric acid followed by Borax and Agricol. The 
interaction effect of different sources and periods was found significant. The highest availability of boron was registered at $45^{\text {th }}$ days of incubation with $10 \mathrm{ppm}$ Boric acid treatment.

\section{References}

Evans, C. M. and Sparks, D. L. (1983). On the chemistry and micrology of boron in pure and in mixed systems. A review. Commun Soil Sci., Pl. Anal., 14: 827-846.

Girish Chander, Verma, T. S. and Sharma, S. (2007). Influence of boron and faryard manure on available boron and exchangeable calcium and their removal by cauliflower in the borondeficient soils of Himachal Pradesh. $J$. Indian Soc. Soil Sci., 55(1): 62-66.

Gupta, U. C. (1968). Relationship of total and hot water soluble boron, and fixation of added boron, to properties of Podzol Soils. Soil Sci. Soc. Am. Proc. 32: 45-48.

Keren, R. and Bingham, F. T. (1994). Boron in water, soils and plants. Edited by Stewart, B. A. Advances in Soil Sci., Published by Springr, Verlay,: 229276.

Khanh et al., (2005) Khanh, V., Kang, Y. and Sakurai, K. (2005). Boron fixation and its release in soils and bark compost. Soil science and plant nutrition. 51(1): 69-74.

Prasad, M. and Byrne, E. (1975). Boron source and lime effect on yield of three crops grown in peat. $J$. Am. Soc. Agron., 67(4): 553-556.

Tisdale, S. L., Nelson, W. L. and Beaton, J. D. (1985). "Soil Fertility and Fertilizer". $4^{\text {th }}$ ed. MacMillan, New York.

\section{How to cite this article:}

Rathod, P.J. and Zalawadia, N.M. 2018. To Investigate the Rate of Release of Boron from Different Sources and Levels of Boron at Varying Period of Incubation. Int.J.Curr.Microbiol.App.Sci. 7(07): 2963-2969. doi: https://doi.org/10.20546/ijcmas.2018.707.346 